\title{
W kontekście 100-lecia niepodległości Polski Mazowsze i jego gospodarka: od Drugiej do Trzeciej Rzeczypospolitej Część pierwsza: Druga Rzeczpospolita
}

\section{Cecylia Leszczyńska}

\author{
STRESZCZENIE
}

Niniejszy artykuł stanowi pierwszą część opracowania dotyczącego gospodarki Mazowsza na przestrzeni minionego stulecia. Przedstawia procesy i zjawiska, które ukształtowały i zdeterminowały strukturę gospodarki regionu w okresie Drugiej Rzeczypospolitej ze wskazaniem historycznego dziedzictwa, w szczególności procesów industrializacyjno-modernizacyjnych z końca XIX w., które miały fundamentalny wpływ na strukturę gospodarki Mazowsza w okresie międzywojennym. Część druga opracowania, dotycząca drugiej połowy XX w. i czasów współczesnych, ukaże się w jednym z następnych numerów czasopisma. Zostanie w niej zwrócona uwaga przede wszystkim na okres transformacji po 1989 r., w tym na dwudziestolecie 1998-2018, kiedy wpływ na gospodarkę regionu i kierunki jej rozwoju miały władze samorządowe województwa mazowieckiego.

Słowa kluczowe: historia Mazowsza, historia polskich regionów, Druga Rzeczpospolita, historia gospodarcza Polski

\section{Wstęp}

Jak powinniśmy definiować Mazowsze pisząc o jego gospodarce w stuleciu 1918-2018? Czy skoro historyczny obszar tej prowincji był - poczynając od czasu rozbiorów wielokrotnie rozczłonkowywany między różne jednostki administracyjne, zachowała ona spójność społeczno-gospodarczą? Jak uchwycić dynamikę i skalę zmian gospodarczych prowincji, skoro konieczne dla ich opisu statystyki tworzone były dla jednostek poziomu wojewódzkiego, których granice nie pokrywały się z historycznym Mazowszem, do tego ulegały zmianom powodując, że mazowieckie powiaty trafiały do różnych województw?

Wskazane wyżej aspekty powoduja, że przedstawienie gospodarki wszystkich subregionów historycznego Mazowsza wymagałoby obszernego opracowania, znacznie przekraczającego limity właściwe artykułom naukowym. Konieczne stało się zatem ograniczenie treści artykułu do najważniejszych procesów gospodarczych. Celem artykułu jest analiza cech gospodarki Mazowsza w okresie Drugiej Rzeczypospolitej, w tym wskazanie czynników, które ukształtowały jej strukturę. Istotną rolę miało tu historyczne dziedzictwo w postaci procesów industrializacyjno-modernizacyjnych z końca XIX w., które określiły warunki międzywojennego „startu”. Procesy gospodarcze dotyczące drugiej połowy XX w. i czasów współczesnych będą przedmiotem odrębnego artykułu, który ukaże się w jednym z kolejnych numerów czasopisma. 
Procesy gospodarcze zachodzące na Mazowszu nie stały się przedmiotem odrębnych studiów monograficznych prowadzonych w konwencji sekularnej. Istniejące syntezy historii Mazowsza dotyczące XIX w. i okresu międzywojennego [Szczepański (red.) 2010, 2012] koncentrują się na sprawach polityczno-społecznych, kwestie gospodarcze zajmują w nich mało miejsca. Zdecydowanie liczniejsze są studia dotyczące współczesności [m.in. Swianiewicz, Dąbrowska (red.) 2018], nie odwołują się one jednak do odleglejszej przeszłości. Dysponujemy natomiast bardzo licznymi studiami i przyczynkami będącymi owocem rozległych badań regionalnych, które dotyczą gospodarki poszczególnych powiatów, miast i niektórych subregionów. Z wyjątkiem monografii miast dotyczą one zazwyczaj krótkich okresów czasu. Przegląd tychże studiów zamieścili autorzy wspomnianych wyżej syntez historii Mazowsza. W niniejszym artykule wykorzystano opracowania odnoszące się bezpośrednio do zagadnień gospodarczych.

\section{Historyczne dziedzictwo}

Mazowsze, podobnie jak inne polskie historyczne prowincje, formowało się na bazie struktur plemiennych, pod względem terytorialnym ukształtował je okres rozbicia dzielnicowego (1138-1320), w trakcie którego dokonał się podział Królestwa Polskiego na separatystyczne księstwa dzielnicowe. Mazowsze, jako odrębne księstwo, uformowało się w czasach Konrada I Mazowieckiego, po jego śmierci dzielone było na coraz mniejsze "księstewka”, czego odbiciem stała się struktura terytorialna dzielnicy. Jak pisała A. Dunin-Wąsowiczowa „Mazowsze charakteryzowało się dużym rozdrobnieniem ziem i powiatów, spowodowanym długotrwałą odrębnością polityczna, licznymi podziałami na niewielkie dzielnice książęce, a przede wszystkim rozrodzeniem drobnej szlachty" [Dunin-Wąsowiczowa 1973, s. 35]. W 1351 r. książęta mazowieccy uznali zwierzchnictwo Kazimierza Wielkiego w formie dożywotniego lenna, ale kiedy po śmierci króla lenno wygasło, uniezależnili się od Korony. Hołdy lennicze złożyli po raz kolejny w latach 14251426 uznając zwierzchnictwo Władysława Jagiełły [Grodziski 2000, s. 107].

W 1462 r. do Korony zostało włączone Księstwo Rawskie i Ziemia Gostyńska (jako województwo rawskie), w 1476 r. Ziemia Sochaczewska (weszła do województwa rawskiego), a w 1495 r. Księstwo Płockie jako województwo płockie. Pozostałe obszary Mazowsza - jako województwo mazowieckie - zostały włączone w 1526 r. po śmierci Janusza III, ostatniego księcia mazowieckiego. Sejm potwierdził tę inkorporację w 1529 r., wiązała się ona z recepcją ustroju Królestwa, organów władzy terytorialnej i przywilejów szlacheckich.

Mazowsze zachowało swoją strukturę terytorialną przez ponad 200 lat, aż do upadku państwa polskiego w końcu XVIII w. Miało obszar 33,5 tys. km² (1580 r.) i dzieliło się na trzy województwa: mazowieckie (23,0 tys. km²), rawskie $\left(6,2\right.$ tys. $\left.\mathrm{km}^{2}\right)$ i płockie $\left(4,3\right.$ tys. $\left.\mathrm{km}^{2}\right)$. Niższą jednostką były ziemie i powiaty, których nazwy nawiązywały do miast będących historycznymi grodami i miejscem obradowania sejmików szlacheckich. Województwo mazowieckie ze stolicą w Czersku, potem w Warszawie, dzieliło się na 10 ziem, województwo rawskie ze stolicą w Rawie na trzy ziemie, płockie ze stolicą w Płocku na 8 powiatów [Gieysztorowa, Łukasiewicz, Zahorski 1968; Gieysztor, Samsonowicz (red.) 1994]. 
Mazowsze należało do słabiej rozwiniętych gospodarczo prowincji Korony, okresy poprawy sytuacji przeplatały się z latami stagnacji. Rozwój gospodarczy dzielnicy i wzrost jej znaczenia politycznego nastąpił w XVI w. Wpływ na to miała ogólna koniunktura gospodarcza (Rzeczpospolita weszła w złoty wiek), dla Mazowsza ważne było podniesienie roli Warszawy: stała się miejscem elekcji królów, zgromadzeń sejmowych i ostatecznie rezydencją królewską. Przejawem ożywienia gospodarki był wzrost liczby ludności miast ${ }^{1}$. Wiek XVII cechowała zmienna sytuacja gospodarcza, od połowy stulecia Rzeczpospolita weszła w kryzys gospodarczy, szczególnie destrukcyjne były wojny toczone z przerwami do początku XVIII w. Ich skutkiem były straty ludnościowe i depopulacja regionu. Liczba ludności z 800 tys. ok. 1578 r. spadła do 365 tys. ok. 1662 r. [Jezierski, Wyczański (red.) 2003, s. 59]. Straty ludnościowe na Mazowszu należały do najwyższych w kraju: dotyczyły 40\% ludności wiejskiej i 70\% ludności miejskiej [Jezierski (red.) 1990, s. 8,20]. Wyraźne ożywienie dokonało się dopiero w drugiej połowie XVIII stulecia. Dotyczyło ono w szczególności Warszawy, gdzie obok tradycyjnych rzemiosł powstało kilka dużych manufaktur, rozwijał się handel i bankierstwo. Nie zmieniło to obrazu całego Mazowsza, u schyłku Rzeczypospolitej pozostało ono obszarem o nisko rozwiniętej gospodarce i dość słabej sieci miejskiej: ok. 1790 r. jedno miasto obsługiwało obszar $311 \mathrm{~km}^{2}$, podczas gdy w Wielkopolsce 188 km², a w Małopolsce 226 km². Liczba ludności Mazowsza ok. 1790 r. wynosiła 518,6 tys. (województwa mazowieckiego 402,3 tys., rawskiego 62,5 tys., płockiego 53,8 tys.). Ludność całej Rzeczypospolitej (bez ziem utraconych w pierwszym rozbiorze) wynosiła wówczas 7660,8 tys. [Jezierski, Wyczański (red.) 2003, s. 53, 62].

W wyniku drugiego i trzeciego rozbioru większość Mazowsza znalazła się w państwie pruskim, jedynie krańce południowe w Austrii. Wprowadzony przez władze pruskie podział na departamenty zrywał z polskimi województwami, zatarciu uległy historyczne granice prowincji. W okresie Księstwa Warszawskiego dominująca część Mazowsza znalazła się $\mathrm{w}$ departamencie warszawskim, pojedyncze powiaty $\mathrm{w}$ departamencie płockim, powiat łomżyński w departamencie łomżyńskim, a garwoliński w siedleckim. W okresie Królestwa Polskiego po 1815 r. jednostką podziału administracyjnego stały się województwa, które nazwami nawiązywały do dawnych tradycji, natomiast terytorialnie bazowały - z pewnymi korektami - na departamentach Księstwa Warszawskiego. Województwo mazowieckie „przejęło" powiaty departamentu warszawskiego, ale także kilka powiatów (brzeski, kowalski i radziejowski), które powstały z części powiatów departamentu bydgoskiego (jako część Wielkiego Księstwa Poznańskiego został włączony do Prus). Warszawa łącznie z Pragą stanowiła odrębny okręg administracyjny wyłączony z województwa mazowieckiego. Województwo płockie „przejęło” powiaty d. departamentu płockiego, z kolei powiat łomżyński znalazł się w województwie augustowskim, a garwoliński w siedleckim [Trzebiński, Borkiewicz 1956, s. 5-7].W 1837 r. województwa przemianowano na gubernie, województwo mazowieckie stało się gubernią mazowiecką. Kilka lat później w 1844 r. w miejsce ośmiu powołano pięć nowych, w tym gubernię warszawską, w której

\footnotetext{
${ }^{1}$ Odsetek ludności miejskiej wynosił ok. 1580 r. 18\%. Był jednak wyraźnie niższy niż w innych prowincjach: w Prusach Królewskich wynosił 37\%, w Małopolsce 30\%, w Wielkopolsce 28\% [Bogucka, Samsonowicz 1986, s. 120-121, 350].
} 
znalazły się gubernia mazowiecka i kaliska; gubernia płocka pozostała niezmieniona, podobnie jak augustowska.

Podział administracyjny został istotnie zmieniony w 1866 r. Gubernia warszawska stanowiła jedną z 10 guberni Królestwa, przesunięciu uległy jej granice: na północnym wschodzie została pomniejszona na rzecz nowo utworzonej guberni łomżyńskiej, z kolei jej południowe krańce włączono do nowo utworzonej guberni piotrkowskiej [Trzebiński, Borkiewicz 1956, s. 91-95]. Gubernię warszawską od 1867 r. tworzyło 13 powiatów, a po korektach z 1893 r. 15 powiatów² ${ }^{2}$ Gubernia płocka dzieliła się na 8 powiatów³ ${ }^{3}$ Granice guberni wytyczone w wyniku reformy z 1866 r., z kilkoma przesunięciami powiatów, przetrwały do 1914 r. W latach 1869-1870 została także przeprowadzona reforma miast, na jej podstawie 336 miastom Królestwa odebrano prawa miejskie przemianowując je na osady: liczba miast spadła do 114. W przypadku guberni warszawskiej liczbę miast zmniejszono z 65 do $22^{4}$. Część miast, którym odebrano prawa miejskie miała cechy wsi, z drugiej strony istniało sporo osad przemysłowych (np. podwarszawski Pruszków), które uznawano za „zurbanizowane wsie”, niemniej praw miejskich im nie nadano [Wawrzyński 2017, s. 32 i nast.].

Co się tyczy procesów gospodarczych, do wyraźniejszych działań promodernizacyjnych doszło w okresie autonomii Królestwa Polskiego, w województwie mazowieckim inicjował je Rajmund Rembieliński, przewodniczący komisji województwa mazowieckiego. Istotny rozwój dotyczył Warszawy, generowały go nowe inwestycje przemysłowe, budowlane (w tym gmachy rządowe) oraz lokowanie w mieście ważnych instytucji finansowych, w tym Banku Polskiego. Województwo mazowieckie zaczęło dominować nad resztą Królestwa Polskiego pod względem liczby warsztatów tkackich: w 1825 r. było ich 2176 (dla porównania w województwie płockim 36, a w całym Królestwie 4012) [Ajzen 1932, s. 127]. Rosła też liczba ludności miejskiej: za sprawą Warszawy województwo miało najwyższy odsetek ludności miejskiej wynoszący 32\% w 1827 r. (w całym Królestwie było to 22\%, w województwie płockim 17\%) [Grynwaser 1951, s. 224-225]. Liczba ludności Warszawy wzrosła z 81 tys. w 1816 r. do 140 tys. w 1829 r. (dodać należy, że około 1794 r. miasto zamieszkiwało więcej ludności niż w 1829 r.).

Po przegranej wojnie z Rosją w 1831 r. i upadku autonomii Królestwa przyszła faza zahamowania rozwoju gospodarczego. Wpłynęło na nią ogólne pogorszenie koniunktury spowodowane spadkiem zbytu na rynek rosyjski, a także wycofaniem się rządu Królestwa i Banku Polskiego ze wspierania wielu przedsięwzięć przemysłowych.

Ożywienie gospodarki Mazowsza, w szczególności Warszawy i podwarszawskich osad, nastąpiło w drugiej połowie wieku. Istotny na nie wpływ miała budowa sieci kolejowej. Inwestycje w tym zakresie generowały zamówienia na dostawy urządzeń,

\footnotetext{
${ }^{2}$ Były to powiaty: warszawski, gostyniński, grójecki, górnokalwaryjski (od 1879 r. włączony do grójeckiego), grodziski (od 1869 r. błoński), kutnowski, łowicki, miński (od 1868 r. nowomiński), radzymiński, skierniewicki, sochaczewski, radziejowski (od 1871 r. nieszawski), włocławski. W 1893 r. do guberni warszawskiej włączono powiat pułtuski z guberni łomżyńskiej i powiat płoński z guberni płockiej. Warto jeszcze wspomnieć o wyłączeniu w 1912 r. powiatu węgrowskiego (historycznie należącego do Mazowsza) z guberni siedleckiej i włączeniu do guberni łomżyńskiej. Związane to było ze zmianami granic guberni siedleckiej z powodu utworzenia guberni chełmskiej.

${ }^{3}$ Były to powiaty: płocki, lipnowski, rypiński, sierpecki, mławski, przasnyski, ciechanowski i płoński.

${ }^{4}$ W 1827 r. województwo mazowieckie liczyło 83 miasta, płockie 43, całe Królestwo 454 [Nietyksza 1986, s. 90, 112, 357].
} 
dawały zatrudnienie, tworzyły magazyny, warsztaty naprawcze, stacje towarowe, wraz z rozbudową sieci małe osady rozrastały się do wielotysięcznych ośrodków komunikacyjnoprzemysłowych ${ }^{5}$. Ponieważ wszystkie linie przebiegały przez Warszawę, miasto stało się centralnym ośrodkiem komunikacyjnym Królestwa z licznymi obiektami związanymi z obsługą ruchu kolejowego [Dobroński 2012, s. 511 i nast.].

W ostatnich dekadach XIX w. nastąpił wyraźny rozwój przemysłowy regionu, o jego dynamice zdecydowało wiele okoliczności: wspomniany wyżej układ sieci kolejowej czyniący z Warszawy największy na ziemiach polskich węzeł kolejowy, historyczne tradycje przemysłowe, skupienie wykwalifikowanej siły roboczej, duży rynek zbytu oraz rozwijająca się wielkomiejska struktura Warszawy [Misztal 1998, s. 22]. Warszawa z okolicznymi osadami utworzyła Warszawski Okręg Przemysłowy, który był drugim (po łódzkim) pod względem zatrudnienia okręgiem Królestwa. W 1913 r. skupiał ponad 40 ośrodków przemysłowych 6 . W przemyśle WOP zatrudnionych było 100 tys. robotników, gdyby doliczyć do tego personel obsługi administracyjnej i inżynieryjno-technicznej liczba ta wzrosłaby do 110-115 tys. Liczba pracowników przemysłowych w Warszawie (w granicach z drugiej połowy XX w.) sięgała 95-100 tys. osób (stan na 1913 r.)[Misztal 1998, s. 21]. Na przełomie XIX i XX w. Warszawa stała się także ważnym ośrodkiem handlowym, finansowym i administracyjnym.

WOP cechowało silne zróżnicowanie dziedzin i gałęzi produkcji, z dominacją kilku branż. Na pierwszym miejscu był przemysł metalowy i maszynowy, tworzyły go zarówno wielkie zakłady przemysłowe, jak i mniejsze firmy. Największe były zakłady mechaniczne Lilpop, Rau i Loewenstein SA, Towarzystwo Przemysłu Metalowego Konstanty Rudzki i Ska SA, Towarzystwo Akcyjne Zakładów Mechanicznych Borman, Schwede i Ska, Fabryka Wyrobów Metalowych i Emaliowanych Wulkan SA oraz Towarzystwo Akcyjne Warsztatów i Emalierni „Labor”. Wszystkie one zatrudniały przed pierwszą wojną od 1 tys. do 2 tys. robotników. Do mniejszych, choć równie znanych, należały m.in. zakłady wyrobów srebrnych i platerowanych Norblina [Morawski 2015, s. 247-248]. Rozwijały się też tereny podmiejskie. Z powodu braku w granicach Warszawy wolnych terenów lub wysokich ich cen, duże i średnie fabryki lokowano dalej od miasta, korzystając także z tańszej siły roboczej. W ten sposób procesem industrializacji objęte zostały nie tylko warszawskie przedmieścia, ale i osady dalej położone, głównie przy liniach kolejowych. Wskazać tu należy Pruszków, Grodzisk Mazowiecki, Jaktorów, Żyrardów, Radziejowice, Mszczonów, Ożarów, Błonie, Mińsk Mazowiecki, Ząbki, Marki, Wołomin, Tłuszcz, Okuniew i Nowy Dwór Mazowiecki. Dla przykładu w Pruszkowie istniały warsztaty kolejowe, zakłady Porcelitu Stołowego „Porcelit”, fabryka ołówków Stanisława Majewskiego, zakłady metalowe H. Hosera,

\footnotetext{
${ }^{5}$ Kolej Warszawsko-Wiedeńska, otwarta w końcu lat 40. XIX w., miała ważne znaczenie dla rozwoju Grodziska, Żyrardowa, Skierniewic; Kolej Warszawsko-Bydgoska (1862) biegła przez Sochaczew, Łowicz i Kutno (do Włocławka i Torunia); Kolej Warszawsko-Petersburska (1862) - przez Tłuszcz i Małkinię; Kolej Terespolska (1867) - przez Mińsk, Siedlce do Terespola i Brześcia. W 1877 r. Kolej Nadwiślańska połączyła Warszawę z Dęblinem i Lublinem, a z drugiej strony z Modlinem, Nasielskiem i Ciechanowem (biegła do Mławy przy granicy z Prusami); Przy tej okazji zbudowano w Warszawie linię obwodową z pierwszym mostem kolejowym (dzisiejszy Most Gdański). W 1903 r. powstała Kolej Kaliska, która połączyła Warszawę z Kaliszem przez Błonie, Łowicz i Łódź [Pruss 1977, s. 19-20].

${ }^{6}$ Zaliczano do nich miejscowości, w których liczba zatrudnionych robotników przemysłowych wynosiła 100 i więcej.
} 
w Grodzisku - zakłady metalowe, a na początku XX w. zakłady farmaceutyczne. Pierwsze kroki zaczął też stawiać Ursus, wiązały się one z Fabryką Armatur i Motorów „Ursus”, powstałą kilka lat przed wybuchem wojny. W podwarszawskim Konstancinie rozwijała się produkcja papiernicza, a we wsi Tarchomin produkcja leków (zakłady farmaceutyczne Ludwika Spiessa) [Morawski 2015, s. 250-251]. We włókiennictwie największą firmą były Zakłady Żyrardowskie zatrudniające na początku XX w. ok. 10 tys. robotników, produkujące wyroby bawełniane i lniane na rynki Rosji i innych państw. Wśród osad fabrycznych związanych z branżą włókienniczą wymienia się też Bieżuń, Chorzele, Marki, Nasielsk, Sierpc, Szreńsk, Wiskitki i Wyszogród. Rozrastały się liczne zakłady rolno-spożywcze, przede wszystkim cukrownie koło Sochaczewa, Łowicza, Gostynina i Płocka, a także młyny, browary, krochmalnie itd. W grupie spożywczej znajdowała się znana warszawska fabryka czekolady Emila Wedla. W innych miastach dominowały lokalne firmy przetwórcze (młyny, garbarnie, olejarnie, fabryki zapałek itd.) [Verdmon 1912, s. 44-69].

Mniej dynamicznie procesy przemysłowe zachodziły w guberni płockiej czy łomżyńskiej. W gospodarce obu guberni dominowało rolnictwo. Wprawdzie można mówić o pewnym przyspieszeniu przemysłowym w końcu XIX i na początku XX w., jednak nie przyniosło ono istotniejszych zmian struktury gospodarki, miało natomiast pewne znaczenie dla rozwoju miejscowych miast ${ }^{7}$. Obie gubernie miały peryferyjny charakter, co ważne, nie przebiegały przez ich stolice linie kolejowe, co było barierą rozwoju większego przemysłu ${ }^{8}$. W przemyśle guberni płockiej na początku XX w. występowały głównie drobne zakłady w branży spożywczej i drzewnej. W Płocku z większych firm wymieniano browar, młyn parowy, spichrze zbożowe nad Wisłą i przystań do ładowania zboża [Verdmon 1912, s. 212213]. Na potrzeby miasta pracowały też małe firmy przetwórcze typu garbarnie, olejarnie, cegielnie itd. Podobny typ zakładów przetwórstwa rolnego występował w Ciechanowie, Sierpcu czy Mławie. Produkcja przemysłowa rozwijana też była w majątkach wielkich właścicieli ziemskich(cukrownie, krochmalnie, młyny, tartaki).W guberni łomżyńskiej także dominowały małe zakłady, kilka średniej wielkości manufaktur powstało w latach 80. XIX w. (w Grajewie, Łomży, Jedwabnem), które wykorzystywały kooperację z białostockimi fabrykami włókienniczymi [Kaczyńska 1974].

Skalę rozwoju przemysłowego wszystkich trzech opisywanych guberni oddają statystyki produkcji przemysłowej około 1913 r. Wartość produkcji przemysłowej w całym Królestwie w 1913 r. wynosiła 898 mln rubli, liczba robotników 412 tys. [Puś 2013, s. 9, 96]. W przemyśle guberni warszawskiej (bez Warszawy i powiatu warszawskiego) w przemyśle pracowało ok. 25 tys. robotników, wartość produkcji przemysłowej sięgała $61 \mathrm{mln}$ rubli [Puś 2013, s. 250]. Z kolei w przemyśle Warszawy i powiatu warszawskiego pracowało 88 tys. robotników, a wartość produkcji przemysłowej to $197 \mathrm{mln}$ rubli. Wartość produkcji przemysłowej guberni płockiej wynosiła $9 \mathrm{mln}$ rubli, liczba robotników przemysłowych sięgała 4 tys., guberni

\footnotetext{
${ }^{7}$ Na przykład Płock liczył w 1913 r. 31 tys. mieszkańców, Łomża 19 tys. (w 1872 r. Płock 20 tys., Łomża 14 tys.) [Nietyksza 1986, s. 368].

${ }^{8}$ Łomża zyskała połączenie w 1915 r. do lokalnej linii biegnącej z Ostrołęki, Płock dopiero w 1934 r. do Sierpca, który w 1936 r. został połączony z Toruniem, a w 1937 r. z Brodnicą.
} 
łomżyńskiej odpowiednio 4 mln rubli i 2,1 tys. [Puś 2013, s. 212-218, 225-230]. Liczby te pokazują mapę zróżnicowania przemysłowego, a przez nie także gospodarczego, wszystkich trzech regionów składających się na historyczne Mazowsze (oczywiście z pewnymi korektami, o których pisałam w pierwszej części artykułu dotyczącej kwestii terytorialnych).

Najwyższy poziom rozwoju gospodarczego mierzony PKB per capita notowała gubernia warszawska. Pod tym względem dystansowała inne obszary Królestwa i osiągała wartości porównywalne z sąsiadującymi z Królestwem niemieckimi rejencjami. W przypadku guberni płockiej i łomżyńskiej poziom PKB per capita był porównywalny ze średnią dla całego kraju [Bukowski, Koryś, Leszczyńska, Tymiński 2018, s. 185].

Gubernia warszawska stała się - za sprawą dynamiki Warszawy - najbardziej zurbanizowaną gubernią Królestwa (ponad 40\% ludności miejskiej na przełomie XIX i XX w., przy średniej dla Królestwa 23\%) ${ }^{9}$. Odsetek ludności rolniczej wynosił (wg spisu z 1897 r.) 35\%, natomiast bez Warszawy 54\% (średnia dla Królestwa to 56\%). Ludność guberni płockiej zamieszkiwała głównie na wsi (80\% w 1897 r.) i utrzymywała się z rolnictwa (60\% w 1897 r.), jedynie dla 10\% źródłem utrzymania był przemysł i zajęcia pokrewne. W guberni łomżyńskiej odsetek ludności wiejskiej to 76\%, z zajęć rolniczych utrzymywało się 65\% ogółu ludności guberni, a z przemysłowych niecałe $10 \%{ }^{10}$.

Największym miastem Mazowsza i całego Królestwa była Warszawa. Wraz z okolicznymi osadami tworzyła całkiem dużą aglomerację („,wielka” Warszawa powstała dopiero w $1914 \mathrm{r}$. poprzez włączenie przedmieść). O ile ok. 1880 r. miasto zamieszkiwało ponad 380 tys. osób, to ok. 1913 r. już 845 tys. Jeszcze dynamiczniej rosła liczba ludności przedmieść (Mokotowa, Ochoty, Młocin czy Bródna), które nie znajdowały się wówczas w granicach miasta [Gawryszewski 2009, s. 56; Bulska 2000, s. 30, 204]. Gospodarkę miasta i regionu tworzyli z jednej strony przemysłowcy, kupcy i bankierzy, z drugiej liczne rzesze migrującej ludności wiejskiej zatrudnianej jako niewykwalifikowana siła robocza w fabrykach, handlu, transporcie, a także jako służba domowa [Bulska 2000, s. 3] ${ }^{11}$.

Wraz z wybuchem wojny nastąpiło zahamowanie produkcji, w szczególności dotyczyło to wielkich zakładów przemysłowych Warszawy. W 1915 r. najważniejsze firmy zostały ewakuowane do Rosji. Działania te, plus zniszczenia wojenne, doprowadziły do poważnej destrukcji przemysłu i gospodarki regionu warszawskiego.

\section{W Drugiej Rzeczypospolitej}

Wraz z powstaniem Drugiej Rzeczypospolitej likwidacji uległy zaborcze jednostki terytorialne, odtworzono podział na województwa. Pod względem terytorialnym bazowały one $\mathrm{w}$ istotnym stopniu na rosyjskich guberniach (zmiana ich granic niosłaby w pierwszym

\footnotetext{
${ }^{9}$ Dane dotyczą 114 miast, które zachowały prawa miejskie po reformie rosyjskiej $1866 \mathrm{r}$.

${ }^{10}$ Ludność miejska obejmuje także ludność tzw. dużych osad. Bez ludności zamieszkującej w osadach odsetek ludności miejskiej wynosiłby w guberni płockiej 16\%, łomżyńskiej 12,3\%, odsetki dla guberni warszawskiej wynosiły odpowiednio 49\% i 44\% [Krzyżanowski, Kumaniecki 1915, s. 104].

${ }^{11}$ Według spisu 1897 r. tylko 52,3\% mieszkańców miasta urodziło się w Warszawie, 14,5 \% urodziło się w guberni warszawskiej, 23,8\% w innych guberniach Królestwa, 7,5\% w Rosji, a 1,9\% w innych państwach.
} 
okresie niepodległości zbyt wiele komplikacji). Podział na województwa i powiaty określiła ustawa z 2 sierpnia 1919 r. o organizacji władz administracyjnych II instancji na terenie b. Królestwa Polskiego oraz ustawa z 4 października 1919 r. o podziale na województwa [Hubert 1922, s. 21-26]. W województwie warszawskim (29,3 tys. km²) znalazły się 23 powiaty przede wszystkim z byłej guberni warszawskiej i płockiej, następnie powiat rawski z guberni piotrkowskiej i makowski z guberni łomżyńskiej. Historycznie „mazowieckie” powiaty jak łomżyński, ostrołęcki, ostrowski, wysokomazowiecki znalazły się w nowo utworzonym województwie białostockim. Stołeczna Warszawa miała status miasta wydzielonego z województwa.

W latach 20. i 30. XX w. pojawiło się wiele projektów zmian podziału na województwa bazujących na wymogach nowoczesnego regionalizmu. Proponowano wytyczenie siatki regionów/prowincji odpowiadających rzeczywistym powiązaniom komunikacyjnogospodarczym i służącym pobudzeniu ich rozwoju, postulowano też rozwój samorządu terytorialnego z szerokimi zadaniami gospodarczo-społeczno-kulturowymi [Nowicki, Patkowski 1926, s 2-3; Leszczyńska 1990, s. 39 i nast.]. Warto wspomnieć o rozwijaniu przez regionalistów postulatów wypracowywania koncepcji zagospodarowania przestrzeni w postaci planów dla regionów. Pierwsze biuro techniczne dla opracowania takiego planu powstało w 1930 r. dla okręgu warszawskiego, w kolejnych latach biura takie tworzono dla innych regionów.

Postulaty dotyczące stworzenia dużych regionów nie zostały zrealizowane, władze uważały bowiem, że ich powołanie wraz z nadaniem im szerokich kompetencji prowadzić będzie do separatyzmów dzielnicowych, które dla młodego państwa mogłyby być groźne. Dokonano natomiast w końcu lat 30. korekty granic województw w celu zatarcia granic byłych zaborów. Dotyczyły one także województwa warszawskiego. Zgodnie z ustawą z 12 czerwca 1937 r. (obowiązującą od 1 kwietnia 1938 r.; Dz.U. RP 1937, nr 46, poz. 350) cztery północno-zachodnie powiaty województwa warszawskiego (lipnowski, nieszawski, rypiński i włocławski) zostały przeniesione do województwa pomorskiego, z kolei powiat działdowski z tegoż województwa - do województwa warszawskiego. Kolejną ustawą z 9 kwietnia 1938 r. (obowiązującą od 1 kwietnia 1939 r.; Dz.U. RP 1938, nr 27, poz. 240) województwo warszawskie powiększone zostało o trzy powiaty i jedną gminę $\mathrm{z}$ województwa lubelskiego (powiat garwoliński, sokołowski i węgrowski) oraz trzy powiaty z województwa białostockiego (łomżyński, ostrołęcki i ostrowski). Na południu województwo mazowieckie pomniejszono z kolei o cztery powiaty włączone do województwa łódzkiego (kutnowski, łowicki, rawski i skierniewicki). Po tych przekształceniach województwo powiększyło się do 31,7 tys. km², a jego granice były bliższe historycznemu Mazowszu. Powiaty województwa w 1939 r. przedstawia rycina 1.

Organami władzy państwowej na poziomie województw byli wojewodowie, na poziomie powiatów - starostowie. Ciałem samorządowym miały być sejmiki wojewódzkie i powiatowe, w rzeczywistości samorząd nie zostałzorganizowany (z wąskimi kompetencjami istniał jedynie w województwie pomorskim i poznańskim, w pozostałych województwach jego namiastkę stanowiła rada wojewódzka i wydział wojewódzki, a na poziomie powiatów 


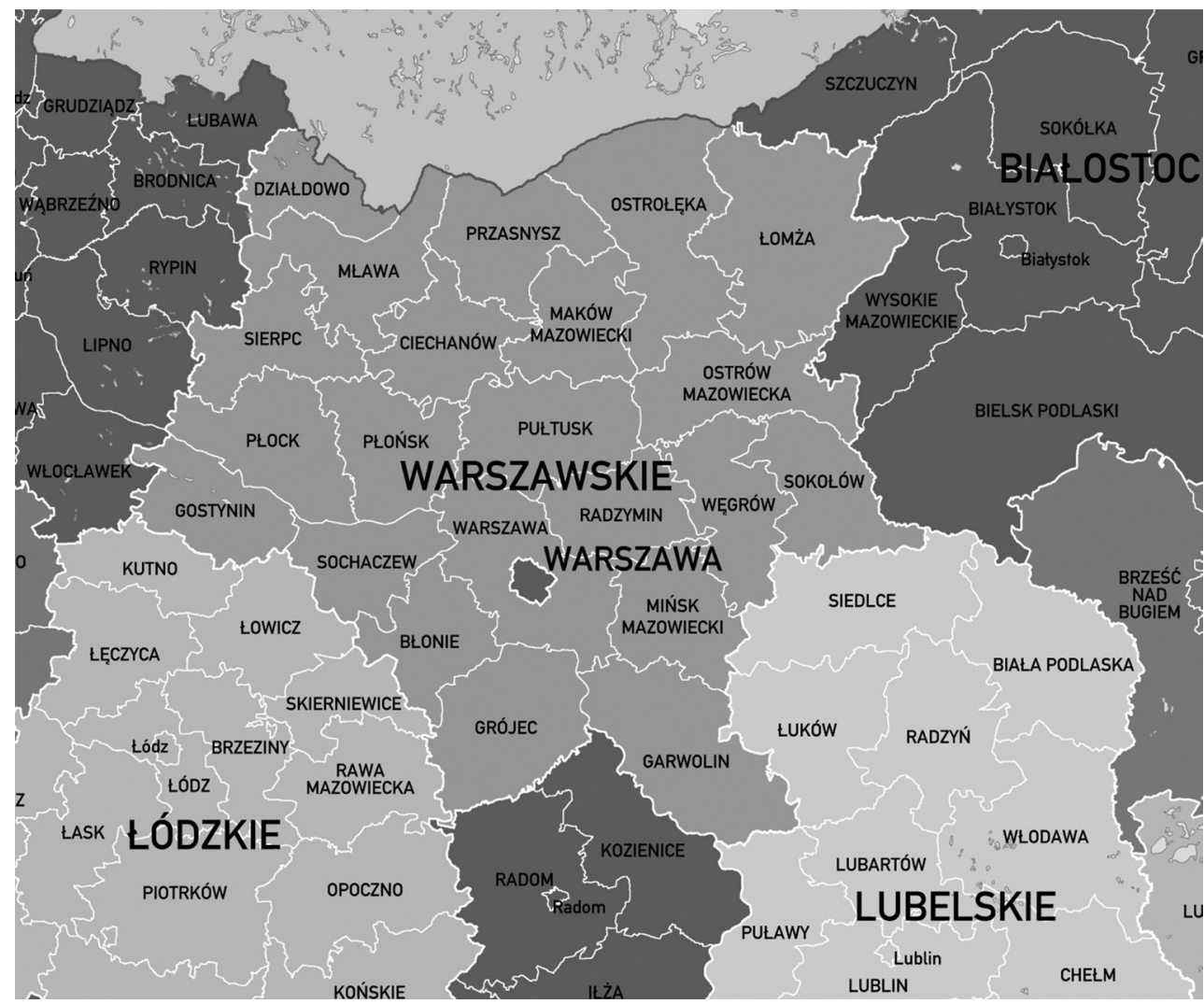

Ryc. 1. Województwo warszawskie w 1939 r.

Źródło: Podział administracyjny II Rzeczypospolitej, https://pl.wikipedia.org/wiki/ [dostęp 25.04. 2019]

rada powiatowa i rada miejska) [Mandzij 1938, s. 5-7, 16-24, 27]. Warszawa, jako stolica państwa, stanowiła odrębną jednostkę administracyjną niewchodzącą w skład województwa warszawskiego. Szefem administracji był od 1919 r. komisarz rządu dla m.st. Warszawy, który łączył funkcje organów I i II instancji (wojewódzkiej i powiatowej). W 1928 r. miasto podzielono na 4 powiaty grodzkie (śródmiejsko-warszawski, południowo-warszawski, północnowarszawski i prasko-warszawski), administrację w nich sprawowali starostowie grodzcy. Warszawa stanowiła zarazem jednostkę samorządu gminnego, a od 1938 r. wojewódzkiego (miała status województwa grodzkiego). Funkcje uchwałodawcze samorządu pełniła rada miejska, a wykonawcze - zarząd miejski i prezydent miasta. Prezydent podlegał ministrowi spraw wewnętrznych, z kolei nadzór nad życiem politycznym stolicy sprawował komisarz rządu. Ustrój władz miejskich regulowany był aktami prawnymi w taki sam sposób jak innych miast [Mandzij 1938, s. 16, 21, 33].

Według spisu z 1921 r. województwo warszawskie (bez m.st. Warszawy) liczyło 2112 tys. mieszkańców, w 1931 r. liczba ta wzrosła do 2529 tys.; liczba ludności Warszawy wynosiła odpowiednio 937 tys. i 1172 tys. (ok. 1289 tys. w 1939 r.). W odniesieniu do struktury 
etniczno-narodowościowej województwo cechował relatywnie wysoki odsetek osób narodowości polskiej (niemal 90\% według spisu z 1921 r.); drugą grupą etniczną byli Żydzi $(8 \%)^{12}$. W powiecie warszawskim (bez Warszawy) struktura ta była podobna, wynosząc odpowiednio 89\% i 9\%. Od reszty województwa odróżniała się Warszawa, w której odsetek ludności narodowości polskiej wynosił 72\%, żydowskiej 27\%, na pozostałe grupy etniczne przypadał ok. 1\% ogółu ludności [Jezierski, Wyczański (red.) 2003, s. 382] ${ }^{13}$.

Mazowsze utrzymało swój wiejski charakter, czego egzemplifikacją jest wysoki odsetek ludności wiejskiej wynoszący w 1921 i 1931 r. ok. 80\%, mieszkańcy miast stanowili około 20\% ludności. Co ciekawe, nie różniły się pod tym względem radykalnie od całego województwa obszary podwarszawskie. Dla przykładu powiat warszawski $\left(1,7\right.$ tys. $\mathrm{km}^{2}$, bez m.st. Warszawy) w 1921 r. zamieszkiwało 182 tys. osób (w tym mieszkańcy miast 24\%, mieszkańcy wsi 76\%), w 1931 r. liczba ludności wzrosła do 326 tys. (w miastach 19\%, na wsi 81\%) [Drugi Powszechny...Wojezwództwo warszawskie 1937, s. 2-3].

Zaprezentowane wyżej odsetki ludności miejskiej powiatu warszawskiego w latach 1921 i 1931 mogą sugerować wręcz dezurbanizację regionu i jego agraryzację. Przeczy temu rosnący odsetek osób utrzymujących się z zajęć miejskich (pozarolniczych): z 50\% w $1921 \mathrm{r}$. do 74\% w 1931 r. ${ }^{14}$ Rozbieżność ta bierze się stąd, że część osad mających charakter miejskoprzemysłowy nie posiadała praw miejskich.

Odzwierciedleniem struktury gospodarki województwa są statystyki pokazujące źródła utrzymania ludności według działów gospodarki. W przypadku całego województwa z zajęć pozarolniczych w 1921 r. utrzymywało się 33\%, a w 1931 r. już 39\% ogółu ludności, wartości te były porównywalne ze średnią krajową [Jezierski, Wyczański (red.) 2003, s. 358, 405]. Wartości dla poszczególnych powiatów pokazuje tabela 1.

\footnotetext{
${ }^{12} \mathrm{~W}$ całym kraju odsetek ludności polskiej wynosił w 1921 r. 69,2\%, żydowskiej 7,8\%, ukraińskiej 14,3\%, białoruskiej $3,9 \%$, niemieckiej 3,9\%, innych $0,9 \%$.

${ }^{13}$ Statystyki te bazują na spisie 1921 r., kiedy zadawano pytanie o narodowość (nie pytano o nią podczas spisu 1931 r.). Nieco odmienny obraz wynika ze statystyk bazujących na wyznaniu i języku. Odsetek osób wyznania rzymskokatolickiego w woj. warszawskim w $1931 \mathrm{r}$. wynosił 86,5\% (w miastach 67,7\%, na wsi 92,2\%), wyznania mojżeszowego $8,7 \%$ (w miastach 29,7\%, na wsi 2,4\%), ewangelickiego 3,7\% (w miastach 2,0\%, na wsi 4,3\%). W odniesieniu do Warszawy odsetek osób wyznania rzymskokatolickiego wynosił 66,9\%, mojżeszowego 30,1\%, ewangelickiego 1,8\%. Dla porównania statystyka wyznaniowa ludności dla całego kraju była w 1931 r. następująca: rzymskokatolickie $64,8 \%$, greckokatolickie 10,4\%, prawosławne 11,8\%, mojżeszowe $9,8 \%$, ewangelickie 2,6\%, pozostałe 0,6\% [Jezierski, Wyczański (red.) 2003, s. 386].

${ }^{14} \mathrm{~W}$ tym przemysł 39\%, handel i ubezpieczenia 9\%, komunikacja i transport 8\% [Drugi Powszechny 1937, s. 78-82; Załęczny 2015, s. 42, 49].
} 
Tabela 1. Ludność według głównych źródeł utrzymania w 1931 r.

\begin{tabular}{|c|c|c|c|c|c|}
\hline \multirow{2}{*}{ Województwo/powiaty } & \multirow{2}{*}{$\begin{array}{l}\text { Ludność } \\
\text { ogółem } \\
\text { w tys. }\end{array}$} & \multicolumn{4}{|c|}{$\begin{array}{c}\text { W tym utrzymująca się z działów gospodarki w \% } \\
\text { ludności ogółem (=100\%) }\end{array}$} \\
\hline & & rolnictwo & przemysł & $\begin{array}{c}\text { handel } \\
\text { i ubezpieczenia }\end{array}$ & $\begin{array}{c}\text { transport } \\
\text { i komunikacja }\end{array}$ \\
\hline Polska ogółem & 31916 & 60,3 & 19,2 & 6,1 & 3,6 \\
\hline Województwo warszawskie & 2529 & 60,9 & 21,2 & 5,5 & 3,5 \\
\hline Warszawski & 326 & 26,4 & 39,3 & 9,2 & 8,0 \\
\hline Błoński (z m. Żyrardów) & 144 & 41,7 & 34,7 & 4,2 & 4,9 \\
\hline Włocławski a & 148 & 43,9 & 33,1 & 8,1 & 2,7 \\
\hline Kutnowski $^{\mathrm{b}}$ & 108 & 54,6 & 24,1 & 6,5 & 6,5 \\
\hline Płocki & 128 & 60,2 & 18,8 & 6,3 & 3,1 \\
\hline Radzymiński & 97 & 61,9 & 20,6 & 6,2 & 4,1 \\
\hline Pułtuski & 118 & 62,7 & 20,3 & 5,9 & 2,5 \\
\hline Skierniewicki ${ }^{\text {b }}$ & 71 & 64,8 & 14,1 & 4,2 & 7,0 \\
\hline Miński & 111 & 67,6 & 17,1 & 5,4 & 2,7 \\
\hline Grójecki & 132 & 68,2 & 17,4 & 5,3 & 2,3 \\
\hline Nieszawski a & 118 & 69,5 & 16,9 & 4,2 & 2,5 \\
\hline Sierpecki & 83 & 71,1 & 15,7 & 4,8 & 1,2 \\
\hline Ciechanowski & 78 & 71,8 & 15,4 & 5,1 & 1,3 \\
\hline Mławski & 103 & 71,8 & 14,6 & 4,9 & 1,9 \\
\hline Sochaczewski & 75 & 72,0 & 16,0 & 4,0 & 2,7 \\
\hline Łowicki ${ }^{\text {b }}$ & 105 & 72,4 & 13,3 & 3,8 & 3,8 \\
\hline Płoński & 81 & 74,1 & 14,8 & 3,7 & 2,5 \\
\hline Gostyniński & 82 & 74,4 & 13,4 & 3,7 & 1,2 \\
\hline Rawski $^{\mathrm{b}}$ & 94 & 75,5 & 13,8 & 3,2 & 1,1 \\
\hline Makowski & 66 & 75,8 & 13,6 & 4,5 & 1,5 \\
\hline Rypiński a & 87 & 77,0 & 12,6 & 3,4 & 1,1 \\
\hline Lipnowski a & 105 & 77,1 & 11,4 & 3,8 & 1,0 \\
\hline Przasnyski & 69 & 79,7 & 11,6 & 2,9 & 1,4 \\
\hline
\end{tabular}

${ }^{\mathrm{ab}}$ W 1939 r. przeniesione do: $a$ - województwa pomorskiego, $b$ - województwa łódzkiego.

W tabeli nie uwzględniono powiatów, które zostały włączone do województwa warszawskiego w 1939 r.

Były to: powiat działdowski, garwoliński, sokołowski, węgrowski, łomżyński, ostrołęcki i ostrowski.

Źródło: Drugi Powszechny....Województwo warszawskie 1937, s. 78-82

Zaprezentowane dane pokazują silne „odstawanie” od przeciętnej dla województwa powiatu warszawskiego, następnie błońskiego i włocławskiego. Jeszcze większe różnice rysują się, gdy powiaty te porównamy z rolniczymi powiatami wschodnimi i południowymi. Analizując owo zróżnicowanie i dodatkowo uwzględniając aspekty kulturowe J. Załęczny wyróżniła pięć regionów kulturowo-gospodarczych Mazowsza: podstołeczny (powiaty: warszawski, grójecki, błoński, radzymiński, miński), mazowiecko-kurpiowski (pułtuski, 
przasnyski, makowski, mławski, ciechanowski), Mazowsze Płockie (płocki, płoński, sierpecki, rypiński, gostyniński), łowicki (łowicki, sochaczewski, skierniewicki, rawski, kutnowski) i kujawsko-dobrzyński (włocławski, nieszawski, lipnowski) [Załęczny 2015, s. 17]. Dodajmy, że w m.st. Warszawa ponad 99\% ludności utrzymywało się z zajęć pozarolniczych, w tym z przemysłu 43\%, handlu i ubezpieczeń 20\%, komunikacji i transportu 9\% [Drugi Powszechny... Miasto st. Warszawa 1937, s. 46 i nast.].

Dynamiczny rozwój przemysłowy, a w związku z tym ogólnogospodarczy, dotyczył przede wszystkim strefy podmiejskiej Warszawy, w której w latach 1921-1931 wzrost liczby ludności wynosił aż 60\%, podczas gdy w całym województwie warszawskim 20\% [Załęczny 2015, s. 17]. Liczba ludności samej Warszawy wzrosła z 937 tys. w 1921 r. do 1172 tys. w 1931 r. i 1289 tys. w 1939 r. (dane dla 1939 r. wg szacunków) [Mały Rocznik Statystyczny 1939, s. 36]. Warto odnotować, że przyrost ludności w strefie podmiejskiej cechował się wyższą dynamiką niż w samej Warszawie. Rozwój stolicy wynikał z rozwoju gospodarczego, ale także pełnionych funkcji administracyjnych, naukowych i kulturowych. Miasto stało się także siedzibą wielu instytucji finansowych i przedstawicielstwa firm pochodzących z innych regionów kraju (z b. Galicji i Wielkopolski). Miasto zyskało lotnisko na Polu Mokotowskim, a od 1938 r. na Okęciu z całkiem dużą siatką połączeń krajowych i międzynarodowych.

O rozwoju przemysłowym regionu warszawskiego decydowała w istotnym stopniu polityka państwa. Okres międzywojenny cechował się silnym wzrostem interwencjonizmu i inwestycji publicznych w sektorze przemysłowym i komunikacyjnym, bardzo silnie państwo angażowało się w sektor zbrojeniowy, którego istotna część znajdowała się właśnie $\mathrm{w}$ regionie warszawskim. Wielkimi inwestorami przemysłowymi stały się przedsiębiorstwa państwowe, w tym wojskowe.

Wokół stolicy uformowały się nowe ośrodki przemysłowe, także w dalej płożonych miejscowościach: Piastów, Milanówek, Pruszków, Grodzisk, Rembertów, Modlin i Legionowo. Wchodziły one w skład Warszawskiego Okręgu Przemysłowego (WOP), który obejmował miasto Warszawę i 5 najbardziej rozwiniętych przemysłowo powiatów: warszawski, błoński, sochaczewski, miński i radzymiński. Część obszaru WOP nabierała cech przemysłowych w końcu XIX w., w międzywojniu uformował się okręg o wyraźnych cech industrialnych, odgrywający coraz ważniejszą rolę na mapie gospodarczej kraju. W WOP dominowały przemysł maszynowy i metalowy, odzieżowy, następnie spożywczy i budowlany ${ }^{15}$.

Rozwój przemysłowy Warszawy nabrał dynamiki w drugiej połowie lat 20., po tym jak zakończył się proces odbudowy przemysłu (w 1927 r. odtworzony został poziom zatrudnienia robotników z 1913 r.). Produkcję uruchomiły wielkie firmy powstałe w XIX w. Były to Zakłady Mechaniczne Lilpop, Rau i Loewenstein SA, które w 1936 r. rozpoczęły produkcję samochodów na licencji General Motors. Zakłady Rudzkiego, specjalizujące się we wznoszeniu obiektów mostowych, zaczęły w latach 30. budować nowe obiekty

\footnotetext{
${ }^{15} \mathrm{~W}$ województwie warszawskim w przemyśle maszynowym i metalowym pracowało 23 tys. osób, odzieżowym 45 tys., spożywczym 29 tys., budowlanym 21 tys., dla porównania w powiecie warszawskim odpowiednio 8,6 tys., 7,3 tys., 7,6 tys., 4,3 tys. [Drugi Powszechny 1937, s. 152-155, 339, 378-379].
} 
w Mińsku Mazowieckim. Działalność wznowiły zakłady chemiczne, browary oraz zakłady Wedla. Następował też proces realokacji przemysłu w mieście, znaczenie traciły stare dzielnice przemysłowe na Powiślu i w Dzielnicy Zachodniej, zyskiwały nowe położone na peryferiach miasta, na Woli i na Pradze. Wola stała się pod koniec lat międzywojennych największą dzielnicą przemysłową Warszawy z 20 tys. pracowników przemysłowych [Misztal 1998, s. 26].

W Warszawie i okolicy lokowano nowe zakłady związane z nowoczesnym przemysłem maszynowym, samochodowym, lotniczym i teletechnicznym. W pierwszej kolejności wskazać tu można zakłady mechaniczne „Ursus”, które w połowie lat 20. podjęły produkcję pierwszych traktorów. Ulokowane we wsi Czechowice pod Warszawą dały początek dużej osadzie przemysłowej. W czasie wielkiego kryzysu firma stała się częścią Państwowych Zakładów Inżynieryjnych (PZInż.) specjalizując się w produkcji zbrojeniowej. Wspomniane PZInż. wyrosły na duży koncern przemysłowy. Zlokalizowane w Warszawie przy ulicy Terespolskiej uruchomiły na licencjach zagranicznych (w tym włoskiego Fiata) produkcję samochodów osobowych i terenowych (te drugie dla wojska). W 1935 r. rozpoczęto produkcję polskich modeli fiata (samochody osobowe i ciężarowe).

Nową dziedziną był przemysł lotniczy, podmiotem dominującym stały się Państwowe Zakłady Lotnicze (PZL) na Okęciu. W latach 30. stworzyły koncern obejmujący wytwórnię silników na Okęciu i płatowców na Paluchu, produkowały bombowce i samoloty myśliwskie. Z sektorem wojskowym związana była Państwowa Wytwórnia Uzbrojenia, mająca - podobnie jak wcześniej wymienione firmy - strukturę koncernowa, w skład której wchodziły firmy warszawskie (karabinów, amunicji) oraz spoza regionu. Inne państwowe podmioty to Państwowa Wytwórnia Aparatów Telefonicznych, od lat 30. Państwowe Zakłady Tele- i Radiotechniczne. Za sprawą inwestycji holenderskiego koncernu "Philips” powstała Polsko-Holenderska Fabryka Lamp Elektrycznych. Ważną rolę odgrywały Polskie Zakłady Optyczne [Morawski 2015, s. 256-258].

W okręgu podwarszawskim rozwinął się Pruszków z Fabryką Obrabiarek stworzoną przez Stowarzyszenie Mechaników Polskich w USA (znana była też fabryka farb drukarskich i fabryka ultramaryny). W Ożarowie zbudowano fabrykę kabli, w Piastowie fabrykę akumulatorów i zakłady chemiczne, w Legionowie wytwórnię balonów, w Sochaczewie i Chodakowie zakłady przędzalnicze, w Milanówku stacją Jedwabniczą. W Jeziornie działała fabryka papieru i zakłady przemysłu chemicznego, w Tarchominie fabryka wyrobów farmaceutycznych, w Helenówku fabryka farb i lakierów. Według S. Misztala w 1937 r. w przemyśle WOP pracowało 102 tys. robotników, czyli 92\% ogółu robotników przemysłowych województwa warszawskiego. W szeroko rozumianej branży przemysłowej (łącznie z rzemiosłem przemysłowym) w WOP pracowało prawie 270 tys. osób [Misztal 1998, s. 24]. W Warszawie i jej przedmieściach, w końcu 1938 r., liczba zatrudnionych robotników przemysłowych dochodziła do 130 tys. i przekraczała poziom z 1913 r. o 30\% (w porównywalnych granicach). W rzemiośle przemysłowym pracowało ok. 100 tys. osób. Rozwój przemysłu w WOP był szybszy niż w innych okręgach przemysłowych na ziemiach polskich (łódzkim czy górnośląskim) [Misztal 1970, s. 208]. 


\section{W KONTEKŚCIE 100-LECIA NIEPODLEGŁOŚCI POLSKI. MAZOWSZE I JEGO GOSPODARKA... \\ Cecylia Leszczyńska}

Dynamiczny rozwój strefy podmiejskiej wymuszał dokonywanie inwestycji infrastrukturalnych, zwłaszcza związanych z podmiejskim transportem (rozwój sieci kolei, w latach 1928-1933 powstała Elektryczna Kolej Dojazdowa).Ważne znaczenie miało uruchomienie w 1920 r. nowej elektrowni w Pruszkowie.

Pozostałe powiaty Mazowsza zachowały w większości rolniczy charakter. Występujący $\mathrm{w}$ nich $\mathrm{w}$ niewielkiej skali sektor przemysłowy cechowała dominacja drobnych, na poły rzemieślniczych firm, zajmujących się przetwarzaniem produktów rolnych i leśnych. Warto odnotować, że w wyniku zmian administracyjnych zrealizowanych w 1939 r. Mazowsze utraciło kilka relatywnie wysoko uprzemysłowionych powiatów północno-zachodnich i południowo-zachodnich, z kolei na północnym wschodzie powiększyło się o kilka powiatów o charakterze wybitnie rolniczym.

Północno-wschodnie Mazowsze było regionem zdecydowanie rolniczym, występujące tam nieliczne zakłady przemysłowe dotyczyły głównie przetwórstwa produktów rolnych i leśnych (browary, gorzelnie, mleczarnie, serowarnie, młyny, fabryki krochmalu, tartaki, garbarnie, zakłady mączki kartoflanej itd.) [Chilczuk 1962, s. 62-63]. Leżące na przeciwległym krańcu powiaty północno-zachodniego Mazowsza miały także charakter rolniczy, niemniej w niektórych silniej obecne było przetwórstwo przemysłowe czy rzemiosło. Do takich należały powiat włocławski czy płocki, ten pierwszy jak pisałam wyżej został w $1939 \mathrm{r}$. przeniesiony do województwa pomorskiego. Należy tu przypomnieć, że powiat włocławski nie jest zaliczany do historycznego Mazowsza, należał natomiast od 1866 r. do guberni warszawskiej, a przez to do międzywojennego województwa warszawskiego ${ }^{16}$.

Włocławek należał do najlepiej uprzemysłowionych miast północno-wschodniego subregionu, ze znanymi fabrykami fajansu, celulozy, papieru, wśród tych drugich wyróżnić należy dużą i nowoczesną Fabryką Sulfit-Celulozy I. \& M. Cassirer powstałą w 1898 r. [Dziki 2015, s. 108]. Wśród innych zakładów wymienić można fabryki cykorii, maszyn rolniczych, drutu oraz szereg drobniejszych zakładów głównie z zakresu przetwórstwa rolno-spożywczego. Firmy te określiły strukturę przemysłu Włocławka w okresie międzywojennym. Dodać należy, że po pierwszej wojnie musiały przejść, podobnie jak zakłady okręgu warszawskiego, trudny proces dostosowania do nowych rynków i nowych odbiorców. Jednocześnie w latach 20. powstało w mieście wiele nowych przedsiębiorstw związanych z meblarstwem, przetwórstwem materiałów budowlanych i ceramiką. Ważną inwestycją była budowa elektrowni pozwalająca na przechodzenie zakładów z napędu parowego na elektryczny. Według danych spisu z 1931 r. z przemysłu utrzymywało się ok. 57\% mieszkańców Włocławka [Drugi Powszechny... Wojezwództwo warszawskie 1937, s. 82], a rozwój gospodarczy miasta oznaczał wzrost liczby jego mieszkańców z 40 tys. w 1921 r. do 68 tys. w 1939 r. [Kamosiński 2015, s. 167-170, 175, 181]. Dla transportu drogowego bardzo ważne znaczenie miało oddanie w 1937 r. mostu stalowego na Wiśle we Włocławku (wcześniej transport obsługiwał tylko most drewniany).

\footnotetext{
${ }^{16}$ Włocławek historycznie należał do Księstwa Kujawskiego, w XIII w. był siedzibą biskupstwa. Związki z Mazowszem dotyczą okresu rozbicia dzielnicowego po 1138 r., kiedy Kujawy należały do Księstwa Mazowieckiego. W końcu XII w. utworzone zostało odrębne Księstwo Kujawskie, ostatecznego „rozdziału” dokonał Konrad Mazowiecki tworząc Księstwo Kujawskie dla swojego syna. Po 1267 r. zostało ono podzielone na Księstwo inowrocławskie i brzesko-kujawskie. Włocławek znalazł się w granicach tego ostatniego.
} 
Zdecydowanie słabiej rozwinięty przemysłowo był Płock. Sam powiat płocki zaliczany do „wybitnie rolniczych”, na 128 tys. mieszkańców w miastach mieszkało 38 tys., z tego w Płocku 31 tys. [Drugi Powszechny...Województwo warszawskie 1937, s. 5]. Gros zakładów przemysłowych skupionych było w samym Płocku, nadmienić jednak trzeba, że w XIX w. nie doszło tam do bardziej znaczącej industrializacji. Przemysł Płocka i powiatu płockiego w okresie międzywojennym zachował swój dziewiętnastowieczny charakter z dominacją zakładów sektora przetwórstwa rolno-spożywczego. Do najbardziej znaczących zaliczano dwie małe fabryki maszyn rolniczych, większa z nich zatrudniała około 100 pracowników. Poza tym w mieście funkcjonowały małe i średnie firmy specjalizujące się w przetwórstwie rolno-spożywczym, swoimi korzeniami często sięgające drugiej połowy XIX w. Wskazać też należy stocznię rzeczną zajmującą się naprawami statków pływających po Wiśle. Na terenie całego powiatu (łącznie z Płockiem) w końcu lat 30. znajdowały się 2 cukrownie (Borowiczki i Mała Wieś), 5 gorzelni, 17 młynów motorowych (w tym największe w Płocku), 20 młynów wodnych, 70 wiatraków, 1 płatkarnia ziemniaków, 1 słodownia jęczmienia, kaszarnia, kilka olejarni, kilka niewielkich fabryk papy i 2 niewielkie fabryki maszyn i narzędzi rolniczych, kilka tartaków na terenie m. Płocka i Wyszogrodu. Istniał też drobny przemysł o charakterze rękodzielniczym i rzemieślniczym: wikliniarski w pasie nadwiślańskim, garncarstwo i „wyrób chodaków” [Kurski (red.) 1938, s. 31, 36].

W 1937 r. w Płocku została oddana do użytku nowa rzeźnia miejska z nowoczesnymi urządzeniami chłodniczymi. Część zakładu dzierżawiła firma E. Hein eksportująca przetwory mięsne, $\mathrm{z}$ tego też względu zbudowano bocznicę kolejową z rampa, magazyny dla puszek i urządzenia chłodnicze. Zmodernizowano też miejską elektrownię (dwie małe prywatne elektrownie powstały już w 1908 r.). Od drugiej połowy lat 20. prowadzono inwestycje poprawiające miejską infrastrukturę: zbudowano wodociągi, opracowano projekty kanalizacji miasta, powstały nowe ulice oraz kolonie urzędnicze i robotnicze. W końcu lat 30. rozpoczęto prace nad budową mostu drogowo-kolejowego przez Wisłę i łącznicy kolejowej Radziwie - Płock [Kurski (red.) 1938, s. 36-38].

Opisany wyżej rozwój gospodarczy Płocka nie należał do „imponujących”, czego wyrazem była relatywnie niska liczba ludności miasta. Przed wybuchem pierwszej wojny światowej wynosiła ona 31 tys., po wojnie spadła do 26 tys. (1921 r.), w 1931 r. osiągnęła poziom przedwojenny (31 tys.), w kolejnych latach wzrosła do 35 tys. (1939 r.) [Kamosiński 2015, s. 152,154, 175]. W końcu XIX w. w przemyśle i rzemiośle Płocka pracowało 1,5 tys. osób, w 1931 r. było to już 5 tys., trudno przy tym wskazać jakąś dominującą gałąź (najwięcej bo 1,2 tys. osób pracowało w przemyśle odzieżowym). Dodajmy, że liczba czynnych zawodowo ogółem wynosiła 12,8 tys. (1931 r.). W handlu i ubezpieczeniach pracowało w 1931 r. prawie 2 tys. osób, w transporcie i komunikacji 0,9 tys., pozostali byli zatrudnieni w innych działach, w tym w administracji publicznej 1,3 tys., prawie 1 tys. osób pracowało jako służba domowa (1931 r.). Największa część ludności miasta (czynni i bierni zawodowo) utrzymywała się z zajęć przemysłowych (13,2 tys.), z handlu i ubezpieczeń 5,0 tys., z komunikacji i transportu 2,8 tys., z pracy w administracji publicznej 3,1 tys. [Kamosiński 2015, s. 171, 181; Drugi Powszechny...Województwo warszawskie 1937, s. 80, 361-363]. 
Na koniec tej części rozważań kilka zdań poświęcić należy trzem powiatom, które wprawdzie nie należały do województwa warszawskiego, ale historycznie zaliczane były do mazowieckich bądź ciążących ku Mazowszu. Chodzi mianowicie o powiat łomżyński, ostrołęcki i ostrowski, które zostały włączone do województwa warszawskiego w 1939 r. Powiat łomżyński zamieszkiwało w 1931 r. 168 tys. osób, w tym z rolnictwa utrzymywało się 117 tys. (prawie 70\%), z przemysłu 24 tys. (14,3\%), z handlu i ubezpieczeń 8 tys. $(4,8 \%)$, z transportu i komunikacji 3 tys. (1,8\%). Dla sporej części mieszkańców źródłem utrzymania były różne zajęcia związane ze służbą publiczną (3,5 tys.) oraz oświatą (1,9 tys.). W przypadku powiatu ostrołęckiego na 112 tys. mieszkańców z rolnictwa utrzymywało się 89 tys. (prawie $80 \%)$, z zajęć przemysłowych 10 tys. (8,9\%), z handlu i ubezpieczeń 3,5 tys. (3,1\%), podobnie z transportu i komunikacji (3,3 tys., 2,9\%). Z zajęć przypisanych do służby publicznej utrzymywało się 1,5 tys. osób, do edukacji 0,9 tys. Mniej rolniczy był natomiast powiat ostrowski. Na ogólną liczbę 98 tys. mieszkańców z rolnictwem związanych było 72 tys. (72\%), z przemysłem 14 tys. (14,5\%), z handlem i ubezpieczeniami 4,2 tys. (4,3\%), z transportem i komunikacją 2,0 tys. (2,0\%), z administracją publiczną 1,3 tys., a z oświatą 1,0 tys. [Drugi Powszechny... Województwo białostockie 1937, s. 70]. Konfrontacja zaprezentowanych wskaźników z danymi z tabeli 1 wskazuje, że powiaty łomżyński i ostrowski plasowałyby się w środku tabeli blisko takich powiatów jak ciechanowski, mławski czy sierpecki, z kolei powiat ostrołęcki na jej dole.

Podsumowaniem powyższych rozważań jest poniższe zestawienie, pokazujące dynamikę i zakres zmian przemysłowych województwa na tle innych województw Polski (niestety nie dysponujemy statystyką produkcji przemysłowej według województw). Wynika z nich, że w okresie międzywojennym Warszawa była drugim, po województwie śląskim, regionem pod względem wskaźnika zatrudnionych w przemyśle na 1000 mieszkańców, z kolei województwo warszawskie znajdowało się w środkowej części stawki. Co się tyczy zmiany liczby pracujących w przemyśle, dynamika Warszawy wyraźnie odstawała in plus w stosunku do reszty kraju. Pokazuje to tabela 2.

Kolejna kwestia warta zasygnalizowania dotyczy zróżnicowania dochodowego ludności Mazowsza na tle innych regionów kraju. Niestety, nie dysponujemy w tym zakresie odpowiednią statystyka, w pewnym stopniu zróżnicowanie to może odzwierciedlać poziom płac według województw. Pokazują go poniższe ryciny.

Przedstawione statystyki są bardzo interesujące. Pokazują wyraźną przewagę w zakresie poziomu płac robotników zatrudnionych w Warszawie, ale także wysoką pozycję województwa warszawskiego. Dodać należy, że poziom płac determinowany był wieloma czynnikami, jednym z ważniejszych była struktura gałęziowa przemysłu dominującego na danym obszarze, niektóre bowiem przemysły (zaliczane do nowoczesnych) cechował ponadprzeciętnie wysoki poziom płac, z kolei przemysły tradycyjne i okołorolnicze (spożywczy, ale też drzewny) bardzo niski poziom płac.

Na koniec kilka zdań o rolnictwie Mazowsza. Jeśli idzie o strukturę agrarną cechowało je dość silne, na tle innych regionów kraju, rozdrobnienie gospodarstw z istotnym udziałem (41\%) gospodarstw poniżej 5 ha (1931 r.). Było ono jednak niższe od średniej dla całego kraju 
Tabela 2. Zatrudnienie w przemyśle według województw w 1935 r.

\begin{tabular}{|l|c|c|c|}
\hline \multirow{2}{*}{ Województwa } & \multicolumn{2}{|c|}{$\begin{array}{c}\text { Robotnicy zatrudnieni w dużych } \\
\text { i średnich zakładach przemysłowych }{ }^{\text {a }}\end{array}$} & $\begin{array}{c}\text { Zatrudnieni w całym } \\
\text { przemyśle na 1000 } \\
\text { ludności w 1935 r. }\end{array}$ \\
\cline { 2 - 3 } Polska & VII 1926 & VII 1938 & $\mathbf{2 0 , 4}$ \\
\hline M. st. Warszawa & 348479 & $\mathbf{6 6 6 4 2 7}$ & 57,2 \\
\hline Warszawskie & 30676 & 86414 & 13,4 \\
\hline Śląskie & 16467 & 47606 & 82,4 \\
\hline Łódzkie & 39953 & 58246 & 48,3 \\
\hline Kieleckie & 83461 & 140807 & 33,6 \\
\hline Krakowskie & 48126 & 84145 & 22,3 \\
\hline Poznańskie & 29391 & 52353 & 20,7 \\
\hline Pomorskie & 39024 & 59314 & 15,6 \\
\hline Białostockie & 14365 & 18757 & 9,8 \\
\hline Lwowskie & 7773 & 20048 & 9,6 \\
\hline Stanisławowskie & 14547 & 33590 & 6,4 \\
\hline Wołyńskie & 8239 & 15469 & 5,9 \\
\hline Wileńskie & 2307 & 15602 & 5,1 \\
\hline Nowogródzkie & 1966 & 6353 & 4,7 \\
\hline Lubelskie & 1076 & 3878 & 4,0 \\
\hline Poleskie & 7648 & 13492 & 3,5 \\
\hline Tarnopolskie & 2091 & 6292 & 3,3 \\
\hline
\end{tabular}

a Zatrudniających 20 i więcej robotników.

Źródło: L. Beskid, Z. J. Wyrozembski (red.), 1956, s. 166; Zatrudnienie w przemyśle 1927, s. 27-29;

Zatrudnienie w przemyśle 1938, s. 251-256

(58,9\%). Wskaźniki ilustrujące zaawansowanie rozwoju rolnictwa mierzone wysokością plonów głównych ziemiopłodów czy hodowli zwierząt były bliskie średnim krajowym. I tak plony żyta z 1 hektara wynosiły ok. 12 kwintali, pszenicy 13 kwintali, jęczmienia i owsa 15 kwintali (średnia dla lat 1928-1937), liczba zwierząt na 100 ha użytków rolnych w przypadku bydła wynosiła 37 sztuk, trzody chlewnej 32 sztuki (1938 r.) [Jezierski, Wyczański (red.) 2006, s. 380-385; Kołodziej 2010].

Po wybuchu drugiej wojny światowej obszary Mazowsza znalazły się w Generalnym Gubernatorstwie, a jego zachodnia część (powiaty gostyniński i działdowski) została włączona do Rzeszy jako regencja ciechanowska. Dystrykt warszawski (17,2 tys. km²) stanowił ok. połowę b. województwa, zostały też doń włączone dwa powiaty b. województwa lubelskiego (siedlecki i część łukowskiego) [Trzebiński 1955, s. 44-49]. Stolicą GG był Kraków. Gospodarka Mazowsza, w szczególności Warszawy, uległa w czasie wojny potężnej destrukcji. Wiele przedsiębiorstw zostało całkowicie zniszczonych, straty majątkowe były ogromne. Po zakończeniu wojny po raz drugi (w stosunku do okresu po pierwszej wojnie światowej) konieczne było podjęcie trudnego procesu odbudowy. 


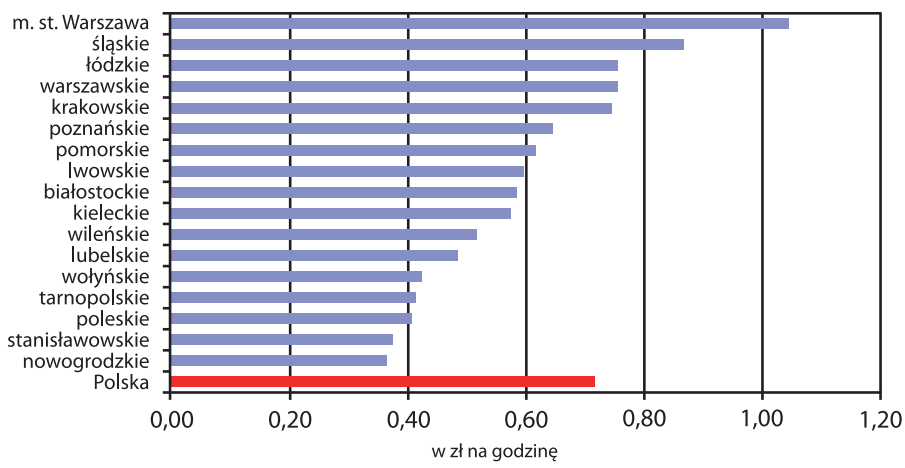

A. Ogółem

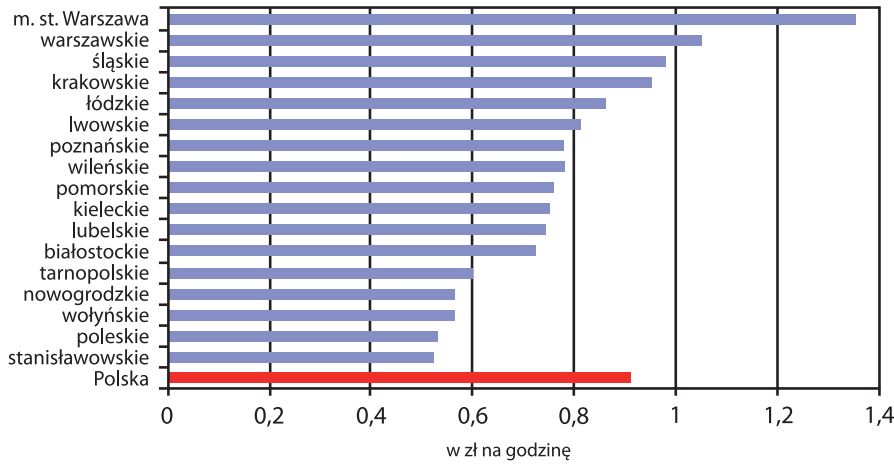

B. Robotnika wykwalifikowanego

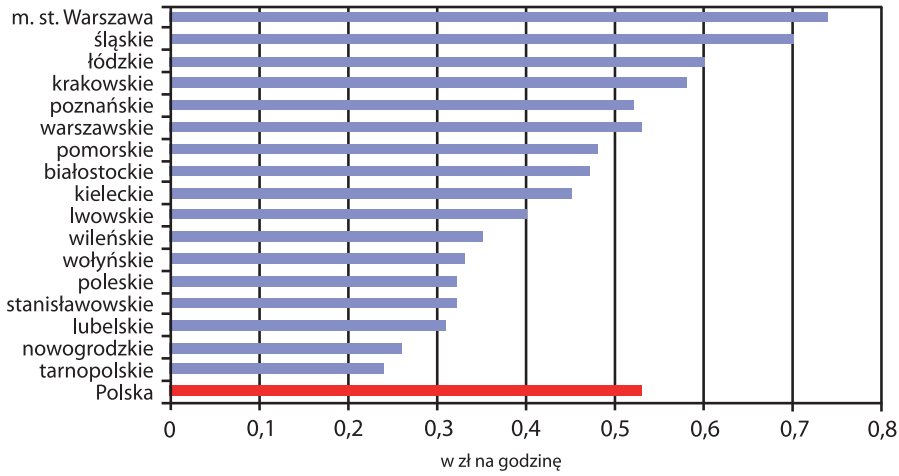

C. Robotnika niewykwalifikowanego

Ryc. 2. Przeciętny zarobek (w zł za godzinę pracy) dorosłego robotnika w przemyśle przetwórczym w sierpniu $1936 \mathrm{r}$.

Uwaga: dane pochodzą z badania obejmującego zakłady zatrudniające 20 i więcej robotników; dotyczą miesiąca wypłaty, w tym przypadku sierpnia; zarobki ogółem dotyczą dorosłych kobiet i mężczyzn, zarobki robotników wykwalifikowanych i niewykwalifikowanych dotyczą jedynie dorosłych mężczyzn. Źródło: opracowano na podstawie: Zarobki robotników w przemyśle przetwórczym, Statystyka Pracy, 1938, 


\section{Podsumowanie}

Mazowsze przez cały analizowany okres należało do regionów rolniczych, statystyki ilustrujące strukturę gospodarki regionu pokazywały, iż pod tym względem nie różniło się ono istotnie od reszty kraju. Region ten cechowały zarazem silne różnice wewnętrzne, przede wszystkim za sprawą przemysłowego subregionu warszawskiego, który gospodarczo istotnie odbiegał od innych obszarów tej prowincji. Subregion ten, nazwany Warszawskim Okręgiem Przemysłowym, uformował się w końcu XIX w., w okresie międzywojennym jego dominująca pozycja uległa zwiększeniu za sprawą szeregu nowych inwestycji przemysłowych i infrastrukturalnych. Na mapie Mazowsza, a precyzyjniej rzecz określając województwa warszawskiego, wyróżniał się ponadto powiat włocławski (do historycznego Mazowsza nie jest zaliczany), z kolei gospodarka historycznie ważnego dla Mazowsza powiatu płockiego z miastem Płock nie zmieniła w międzywojniu w sposób istotny swojej tradycyjnej struktury uformowanej w XIX w. Wydaje się zatem, że okres międzywojenny przyniósł przyspieszenie gospodarcze przede wszystkim okręgowi warszawskiemu oraz samej Warszawie, które jeszcze wyraźniej niż w XIX w. zaznaczyły swój dystans i przewage w stosunku do pozostałej części Mazowsza. 


\section{Literatura}

Ajzen M., 1932, Polityka gospodarcza Lubeckiego (1821-1830), Towarzystwo Naukowe Warszawskie, Warszawa.

Beskid L. ,Wyrozembski Z. J. (red.), 1956, Materiały do badań nad gospodarka Polski, cz. I, 19181939, PWN, Warszawa,

Bogucka M., Samsonowicz H., 1986, Dzieje miast i mieszczaństwa w Polsce przedrozbiorowej, Zakład Narodowy im. Ossolińskich, Wrocław.

Bukowski M., Koryś P., Leszczyńska C., Tymiński M., 2018, Rozwój regionalny ziem polskich pod zaborami,. Porównanie poziomu produktu brutto per capita na dzisiejszych terenach Polski na przełomie XIX I XX w. Wyniki pierwszych estymacji, Roczniki Dziejów Społecznych i Gospodarczych, t. 78 .

Bulska B. M., 2000, Warszawa u schyłku XIX i na progu XXI wieku w dokumentacji statystycznej, GUS, Warszawa.

Chilczuk M., 1962, Rozwój i rozmieszczenie przemystu rolno-spożywczego w województwie białostockim, Prace Geograficzne, 37, Instytut Geografii PAN, Warszawa.

Dobroński A. Cz., 2012, Społeczeństwo i gospodarka Mazowsza w latach 1865-1914 [w:] J. Szczepański (red.), Dzieje Mazowsza. Lata 1795-1918, t. 3, Akademia Humanistyczna im. Aleksandra Gieysztora, Pułtusk.

Drugi Powszechny Spis Ludności z dn. 9.XII 1931 r. Miasto st. Warszawa, 1937, Statystyka Polski, seria C, z. 49.

Drugi Powszechny Spis Ludności z dn. 9.XII 1931 r. Województwo biatostockie, 1938, Statystyka Polski, seria C, z. 83.

Drugi Powszechny Spis Ludności z dn. 9.XII 1931 r. Województwo warszawskie, 1937, Statystyka Polski, seria C, z. 57.

Dunin-Wąsowiczowa A., 1973, Podziały administracyjne [w:] W. Pałucki (red.), Mazowsze w drugiej połowie XVI wieku, cz. 2., Instytut Historii PAN, Warszawa.

Dziki T., 2015, Włocławska fabryka Sulfit-Celulozy I. E M. Cassirer w latach 1898-1920, Studia z Historii Społeczno-Gospodarczej, t. 15.

Gawryszewski A., 2009, Ludność Warszawy w XX wieku, Monografie, 10, Instytut Geografii i Przestrzennego Zagospodarowania im. Stanisława Leszczyckiego PAN, Warszawa.

Gieysztor A., Samsonowicz H. (red.), 1994, Dzieje Mazowsza do 1526 roku, PWN, Warszawa. 
Gieysztorowa I., Łukasiewicz J., Zahorski A., 1968, Cztery wieki Mazowsza. Szkice z dziejów 1526-1914, Nasza Księgarnia, Warszawa.

Grodziski S., 2000, Uwagi o inkorporacji Mazowsza - lenna Korony, Zeszyty Naukowe Ostrołęckiego Towarzystwa Naukowego, 14.

Grynwaser H., 1951, Demokracja szlachecka. Pisma, t. 1, PWN, Wrocław.

Hubert J., 1922, Sprawa nowego podziału Rzeczypospolitej Polskiej na województwa, Biblioteka „Przeglądu Administracyjnego", Poznań.

Jezierski A. (red.), 1990, Historia Polski w liczbach. Terytorium i ludność, z. 1, GUS, Warszawa.

Jezierski A., Wyczański A. (red.), 2003, Historia Polski w liczbach, t. 1, Państwo. Społeczeństwo, GUS, Warszawa.

Jezierski A., Wyczański A. (red.), 2006, Historia Polski w liczbach, t. 2, Gospodarka, GUS, Warszawa.

Kaczyńska E., 1974, Gospodarka i społeczeństwo pótnocno wschodnich ziem Królestwa Polskie w okresie rozkwitu kapitalizmu, Wyd. Uniwersytetu Warszawskiego, Warszawa.

Kamosiński S., 2015, Miasta przemystowe dolnej Wisty [w:] Ł. Dwilewicz, W. Morawski (red.), Historia polskich okręgów i regionów przemysłowych, t. 1, Pracownia Wydawnicza \& Akant, Warszawa.

Kołodziej E., 2010, Życie gospodarcze [w:] J. Szczepański (red.), Dzieje Mazowsza. Lata 1918-1939, t. 4, Akademia Humanistyczna im. Aleksandra Gieysztora, Pułtusk.

Krzyżanowski A., Kumaniecki K., 1915, Statystyka Polski, Polskie Towarzystwo Statystyczne, Kraków.

Kurski I. J. (red.), 1938, Kalendarz i Informator Mazowsza Płockiego i ziem sasiednich na rok 1939, Wydawnictwo Braci Detrychów, Płock.

Leszczyńska C., 1990, Województwo w II Rzeczypospolitej [w:] A. Kukliński, P. Swianiewicz (red.), Polskie województwo. Doświadczenia i perspektywy, Instytut Gospodarki Przestrzennej Uniwersytetu Warszawskiego, Warszawa.

Mały Rocznik Statystyczny 1939, 1939, GUS Rzeczypospolitej Polskiej, Warszawa.

Mandzij M., 1938, Ustrój i działalność samorządu terytorialnego w Polsce, R. Serednicki, Kielce.

Misztal S., 1970, Przemiany w strukturze przestrzennej przemysłu na ziemiach polskich w latach 1860-1965, PWN, Warszawa 1970.

Misztal S., 1998, Przekształcenia struktury przemystu Warszawy, Atlas Warszawy, 6, Instytut Geografii i Przestrzennego Zagospodarowania im. Stanisława Leszczyckiego PAN, Warszawa. 
Morawski W. 2015, Warszawski Okręg Przemysłowy [w:] Ł. Dwilewicz, W. Morawski (red.), Historia polskich okręgów i regionów przemysłowych, Oficyna Wyd. SGH, Warszawa.

Nietyksza M., 1986, Rozwój miast i aglomeracji miejsko-przemysłowych w Królestwie Polskim 1865-1914, PWN, Warszawa.

Nowicki Z., Patkowski S., 1926, Program regionalizmu polskiego, Polska Oświata Pozaszkolna, 4-5.

Pruss W., 1977, Rozwój przemystu warszawskiego w latach 1864-1914, PWN, Warszawa.

Puś W., 2013, Statystyka przemysłu Królestwa Polskiego 1879-1913. Materiały źródłowe, Wyd. Uniwersytetu Łódzkiego, Łódź.

Swianiewicz P., Dąbrowska A. (red.), 2018, Mazowsze - ekonomia i gospodarka, Wydawnictwo Naukowe PWN, Warszawa.

Szczepański J. (red.), 2012, Dzieje Mazowsza. Lata 1795-1918, t. 3, Akademia Humanistyczna im. Aleksandra Gieysztora, Pułtusk.

Szczepański J. (red.), 2010, Dzieje Mazowsza. Lata 1918-1939, t. 4, Akademia Humanistyczna im. Aleksandra Gieysztora, Pułtusk.

Trzebiński W., 1955, Niemieckie podziaty administracyjne ziem polskich w okresie 1815-1945. Zarys historyczny, Dokumentacja Geograficzna, 9, Instytut Geografii PAN, Warszawa.

Trzebiński W., Borkiewicz A, 1956, Podziały administracyjne Królestwa Polskiego w okresie 18151818. Zarys historyczny, Dokumentacja Geograficzna, 4, Instytut Geografii PAN, Warszawa.

Verdmon L. J., 1912, Krótka geografia Królestwa Polskiego, Skład Główny Księgarni Aleksandra Lewińskiego,Warszawa.

Wawrzyński M., 2017, Życie publiczne i społeczne Pruszkowa do roku 1921. Dynamika rozwoju peryferyjnego, Książnica Pruszkowska, Pruszków.

Załęczny J., 2015, Powiat warszawski w latach II Rzeczypospolitej. Życie społeczno-polityczne, gospodarcze i kulturalne, Muzeum Niepodległości, Warszawa.

Zarobki robotników w przemyśle przetwórczym, 1938, Statystyka Pracy, z. 1, 4.

Zatrudnienie w przemyśle, 1927, Statystyka Pracy, z. 1.

Zatrudnienie w przemyśle, 1938, Statystyka Pracy, z. 4. 
In the context of the 100th anniversary of Poland's independence Mazovia and its economy: from the Second to the Third Republic

Part one: The Second Republic

\section{ABSTRACT}

This article is the first part of the study on the Mazovian economy over the last century. It presents processes and phenomena that shaped and determined the structure of the region's economy in the Second Polish Republic with an indication of historical heritage, in particular industrialization and modernization processes in the late nineteenth century, which had a fundamental impact on the structure of the Mazovian economy in the interwar period. The second part of the study (on the second half of the twentieth century and modern times) will be published in one of the next issues of the journal.

Key words: history of Mazovia, history of Polish regions, Polish Second Republic, economic history of Poland

$\overline{\text { Cecylia Leszczyńska, }}$ dr hab., Wydział Nauk Ekonomicznych Uniwersytetu Warszawskiego. Jest autorką/współautorka publikacji z dziedziny historii gospodarczej, statystyki historycznej, historii bankowości i pieniądza. E-mail: cleszczynska@wne.uw.edu.pl

Cecylia Leszczyńska, dr hab., Faculty of Economic Sciences, University of Warsaw. She has published articles and books on the economic history of Poland, history of Polish central banking and Polish historical statistics. E-mail: cleszczynska@wne.uw.edu.pl 